\title{
Evaluation of paper recycling wastewater treatment accompanied by power generation using microbial fuel cell
}

\author{
Radha M. ${ }^{1, *}$ and Kanmani S. ${ }^{2}$ \\ ${ }^{1}$ Anna University, Chennai- 600 025, Tamil Nadu \\ ${ }^{2}$ Center for Environmental Studies, Anna University, Chennai- 600 025, Tamil Nadu. \\ Received: 07/02/2016, Accepted: 19/09/2017, Available online: 19/12/2017 \\ *to whom all correspondence should be addressed: e-mail: radhasiva.phd@gmail.com
}

\begin{abstract}
This study investigates the feasibility of using cathode catalyst (Iron phthalocyanine (FePc) combined multi walled carbon nano tubes (MWCNT) and compares the oxygen reduction rate under different conductivity of catholite solution (50 mM, 100mM) in double chamber Microbial Fuel Cell. Microbial fuel cell (MFC) research is going on for few decades to increase the power density and improve the removal efficiency. Iron phthalocyanine (FePc) combined multi walled carbon nano tubes (MWCNT) cathode catalyst showed the highest power density $\left(9.34 \mathrm{w} / \mathrm{m}^{2}\right)$ in $100 \mathrm{mM}$ PBS than $50 \mathrm{mM}\left(7.58 \mathrm{~W} / \mathrm{m}^{2}\right)$. The electrodes are characterized by scanning electron microscopy (SEM) and the electrocatylitic activity of the catalyst coated electrodes were examined by cyclic voltammetry(CV). The high power density indicates a potential alternative to precious platinum metal catalyst in treatment as well as electricity production Microbial Fuel cell.
\end{abstract}

Keywords: Iron phthalocyanine, Multiwalled carbon Nano Tubes, electrocatalytic, conductivity.

\section{Introduction}

Energy is the prime mover of economic growth of a country's economy. Future economic growth significantly depends on the extensive availability of energy sources. Previous works says the treatment efficiency is mainly limited wastewater conductivity (Bruce E Logan et.al., 2008). Different types of wastewater have been successfully treated by MFC (Velasquez-Orta, 2011). Bacteria in an MFC grow under anoxic condition which can benefit cellulose fermentation and degradation with the added benefits of electricity generation rather than power consumption (Logan et al., 2008). Wastewater contains lot of easily degradable organic matter which are metabolized by the active bacterial species present in wastewater itself and produces electricity during the course (Jang et al., 2004) In a double chambered salt bridge MFC, the sludge organic matter is oxidized with simpler compound in the anode chamber (Mohan et al., 2008) The fuel cell performance is based on the fuel transport to the microorganisms and metabolic activity and examined the effectiveness of MFC using Membrane Electrode Assembly (MEA) (Lovely et al., 2003). A chamber MFC for anode material up gradation is an important parameter (Rabaey et al., 2006).

Performance of SCMFC on Nafion 117 and SPSEBS (polymer) membrane are compared using Pt catalyst (Dharmalingam et al., 2012). The use of Manganesepolypropelene-carbon nano tube (Mn-PPY-CNT) has been demonstrated to have potential to replace platinum $(\mathrm{Pt})$ in oxygen reduction rate (ORR) (Lu et al., 2013). However, platinum metal as an expensive catalyst while scale up the reactor, a more cost effective $\mathrm{MnO}_{2}$ with activated carbon can replace Pt (Chandra et al., 2013; Zhu et al., 2013). Ammonia treated activated carbon presence of peat inceases the nitrogen functional group improves the ORR activity (Logan et al., 2013). Polyanilene-Iron-carbon (PANIFe-C) having specific surface area $\left(228.3 \mathrm{~m}^{2} / \mathrm{g}\right)$ lesser than Pt $\left(733.9 \mathrm{~m}^{2} / \mathrm{g}\right)$ but power density is high due to its chemical structure (Li et al., 2013)

In present study shown, Pt free catalyst is chosen for economic point of view. Recently, use of MWCNT/FePc catalyst particle having significance of ORR in MFC. Electrocatalytic activity of the MWCNT supported FePc compared with bare graphite felt. Performance of the MWCNT/FePc catalyst in MFC was due to four electron path way (Yong et al., 2011). The composite catalyst having potential in ORR comparable to platinum \& many researches have been conducted to develop a new nonnoble metal as an electro catalyst to replace or reduce the amount of Pt (Zhao et al., 2005; Ahmed et al., 2012; Birry et al., 2011; Yong et al., 2011).

\section{Materials and Methods}

\subsection{Electrode preparation}

Catalytic ink is prepared by dispersing the catalyst in isopropyl alcohol solvent followed by mixing $10 \%$ Nafion ( $5 \%$ wt Nafion from Sigma Aldrich) solution for total weight of catalyst to bind the catalyst with electrode. The catalytic ink is sprayed over the electrode and dried for $70{ }^{\circ} \mathrm{C}$ to evaporate the solvent. By the above said method graphite felt is modified as (FePc/MWCNT) catalyst coated electrode. Multiwalled carbon nanotubes (MWCNT (>80\% 
pure, Nano shell, USA), Iron phthalocyanine (FePc, SigmaAldrich) MWCNT has a surface area of 90-350 $\mathrm{m}^{2} / \mathrm{g}$ with a diameter of $20-30 \mathrm{~nm}$ and length of $5-1 \mu \mathrm{m}$. FePc has a carbon and Nitrogen content of $67.3 \%$ \& $19.5 \%$ respectively $657 \mathrm{~nm}$.

\subsection{MFC construction and operations}

Double chambered Microbial fuel cell (DCMFC) is constructed as reported previously (Limson et al., 2014). Anodic and cathodic chambers are separated by PEM (Nafion ${ }^{\circledR} 117$, Dupant \& co) membrane of size $2.5 \mathrm{~cm}$ diameter (Area $4.906 \mathrm{~cm}^{2}$ ), both chambers are made of borosilicate in cylindrical shape with volume of $250 \mathrm{ml}$ each. PEM is held by clamp between two flattened chamber Interspace with air tight gasket. The spacing between anode and cathode are maintained as $12 \mathrm{~cm}$. Anode carbon cloth $(3 \mathrm{~cm} \times 3 \mathrm{~cm})$ and cathode graphite felt $(3 \mathrm{~cm} \times 3 \mathrm{~cm})$ (sienergy fuel cell store, India) connected by copper wire with an external resistor $66 \Omega$ to the multimeter. Anolite of Paper recycling wastewater with inoculum and catholyte of PBS (50 mM, 100mM) with potassium permanganate are used. The $\mathrm{pH}$ is maintained as 6.9 by adding $\mathrm{NaOH}$ or $\mathrm{HCl}$. Paper recycling wastewater collected from the collecting tank after primary clarifier and stored below $4{ }^{\circ} \mathrm{C}$ until its use. Characteristics of wastewater are summarized in Table 1 . Mixture of Sludge and soil collected from the paper recycling mill is used as an inoculum. Every time the reactor solution should be replaced, when the voltage dropped $50 \mathrm{mV}$ and some quantity should be left in the reactor to inoculate the next cycle wastewater treatment. Anode and cathode chambers are maintained in anaerobic condition and aerobic condition respectively. The cathode chamber is aerated by fish tank aerator. The total setup was operated at room temperature at $29^{\circ} \mathrm{C}$ in a fed batch mode. Before starting up the experiment both compartments are sterilized by autoclave for 20 minutes. The Nafion 117 membrane is pretreated with hydrogen peroxide solution followed by distilled water each one hour and the electrodes are pretreated by soaking in $1 \mathrm{M} \mathrm{HCl}$ followed by $1 \mathrm{~N} \mathrm{NaOH}$ for whole night before giving a catalyst coating.

Table 1. Characteristics of paper recycling wastewater

\begin{tabular}{ccc}
\hline Parameters & Units & Average value \\
\hline BOD $_{5}$ & $\mathrm{mg} / \mathrm{l}$ & 615 \\
\hline COD & $\mathrm{mg} / \mathrm{l}$ & 1792 \\
\hline Chlorides & $\mathrm{mg} / \mathrm{l}$ & 257 \\
\hline Oil and Grease & $\mathrm{mg} / \mathrm{l}$ & 78 \\
\hline $\mathrm{pH}$ & & 7.12 \\
\hline $\mathrm{TSS}$ & $\mathrm{mg} / \mathrm{l}$ & 158 \\
\hline TDS & $\mathrm{mg} / \mathrm{l}$ & 1428 \\
\hline Sulphates & $\mathrm{mg} / \mathrm{l}$ & 85 \\
\hline Colour & & Turbid
\end{tabular}

\subsection{Analysis}

Cyclic voltammetry is recorded at a scan rate of $50 \mathrm{mV} / \mathrm{s}$ over the potential window from +0.5 to $-0.5 \mathrm{~V}$. Electrochemical tests of the electrodes are done using 3 electrode setup by using Pt working electrode and $\mathrm{Ag} / \mathrm{AgCl}$ reference electrode. The voltage across the external resistor is monitored with 10 hrs intervals using multimeter. Surface morphology is done by SEM analysis for catalyst coated and bare graphite felt. Power density and substrate degradation are considered as the two Main parameters to estimate the performance of fuel cells. Current production is calculated by Ohms law $V=I \times R$ where I-Current in ampere, V-Voltage in volts, R-Resistor in $\Omega$, Power output $(P)=I \times V$ where power in Watts, Current density (C.D) $=I_{\max } / A$, Power Density (P.D) $=P_{\max } / A$ where Asurface area of the electrode. Columbic efficiency (CE) is calculated from the formula given below

$$
C E=\frac{8 \cdot \int_{0}^{t} I d t .}{F \cdot V \cdot \triangle C O D}
$$

Where $\mathrm{F}$ is the Faraday constant, I is the harvested current, $V$ is the volume anode, and 8 are the grams per electron in oxygen. Chemical Oxygen Demand (COD) was measured from wastewater by standard methods (APHA) open reflux method. Total dissolved solids total solids are also measured according to standard methods (Rabaey et al., 2006) and Biochemical Oxygen Demand were measured by the standard methods.

\section{Results and Discussion}

\subsection{Electrode Morphology}

Surface morphology of catalyst coated electrode is analyzed by scanning electron microscope (SEM) at $5 \mathrm{KV}$. From the SEM images, The FePc is dispersed over the MWCNT at the external pores of coatings indicated in the Fig. 1a. Surface of bare graphite felt is very smooth (shown in Fig. 1b). MWCNT powders absorbed on the surface of FePc coated electrodes which improves the oxygen reduction rate. Different types of bacterial attachment are identified, which acts as a biocatalyst and assist the transfer of electrons from anolite to electrode.

\subsection{Electrocatalytic characterization}

From the readings of Cyclic Voltammetry (CV) is an enhancement in the electrocatalytic properties of various electrodes. Fig 2 shows that the CV of different nano composite electrodes at the scan rate of $10 \mathrm{mVs}^{-1}$. In the present study compare the Electrocatalytic activity of FePc/MWCNT and bare graphite felt (GF) are compared in 
$100 \mathrm{mM}$ and $50 \mathrm{mM}$ PBS with $5 \mathrm{Mm}$. Potassium permanganate electrolyte are compared under oxygen saturated condition. The electrode FePc/MWCNT produced maximum of peaks on $\mathrm{CV}$, with $+0.18 \mathrm{~V}$ in 100

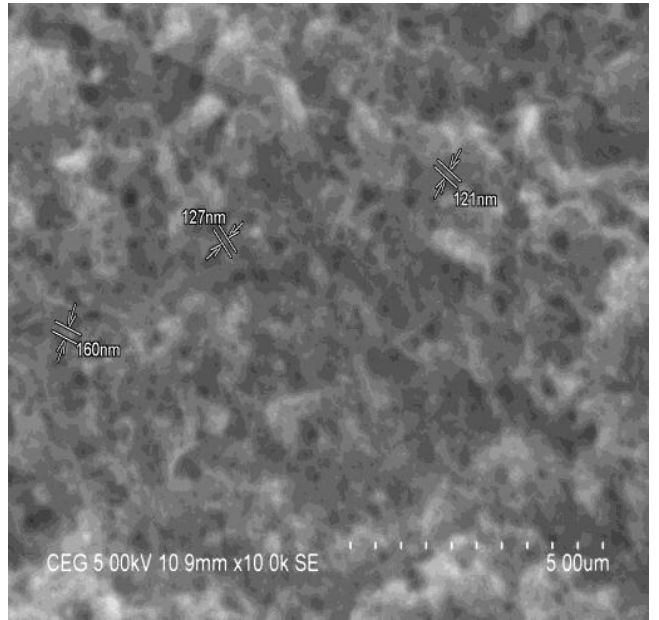

(a)
$\mathrm{mM}$ PBS at the scan rate of $10 \mathrm{mV} \mathrm{s}^{-1}$, the peaks were not present in bare GF and MWCNT. The peaks may be due to PcFc effect.

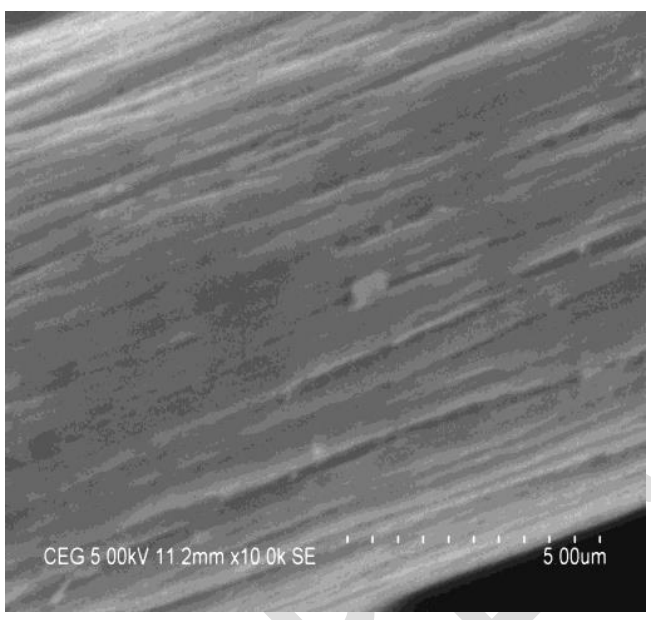

(b)

Figure 1. SEM images of (a) FePc/MWCNT coated electrode (b) Bare Graphite felt

From the previous study the first peak is at $+0.12 \mathrm{~V}$ and the second peak is at $-0.51 \mathrm{~V}$ to the CNT on $\mathrm{Pt}(\mathrm{CNT} / \mathrm{Pt})$ was greater than CNT alone (Ghamesi et al., 2013).The first peak is due to ligands of PcFc and the second peak is due to redox reaction (Ha et al., 1999).MWCNT/FePc produced two peaks, but the peaks were not present in MWCNT (Yuan et al., 2011). The peak potential of $+0.19 \mathrm{~V}$ for FePc is more positive potential than other electrodes, which proves that the FePc/MWCNT had most effective ORR activity. Electrochemical activity of electrodes is greatly enhanced by associating nitrogen groups in the CNT (Gong et al., 2009). MWCNT enhance the promising ORR activity, however the oxygen reduction potential is further improved by introducing MWCNT with FePc (Yuan et al., 2011).

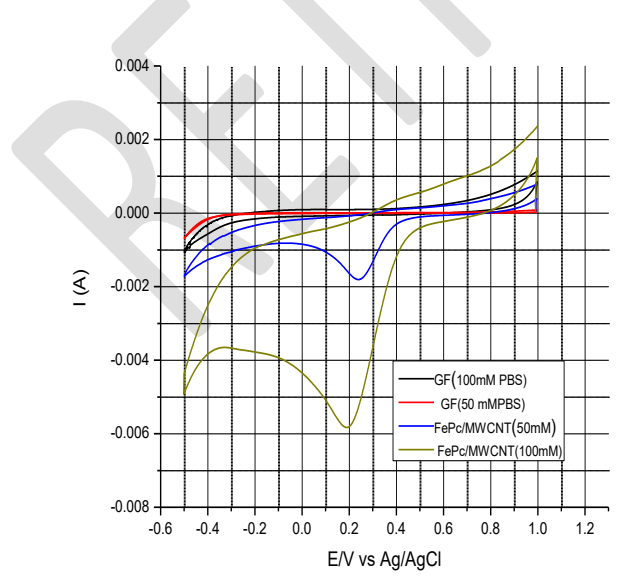

Figure 2. CV characterization of FePc/MWCNT and Bare Graphite felt in $100 \mathrm{mM}$ and $50 \mathrm{mM}$ PBS
3.3 The performance of MFCs with power density production

Bioelectricity is successfully obtained from a Double chambered Microbial Fuel Cell by using different cathode catalyst inoculated with soil and sludge collected from paper recycling mill premises. Power density versus current density is plotted in graph as shown in Fig 3.

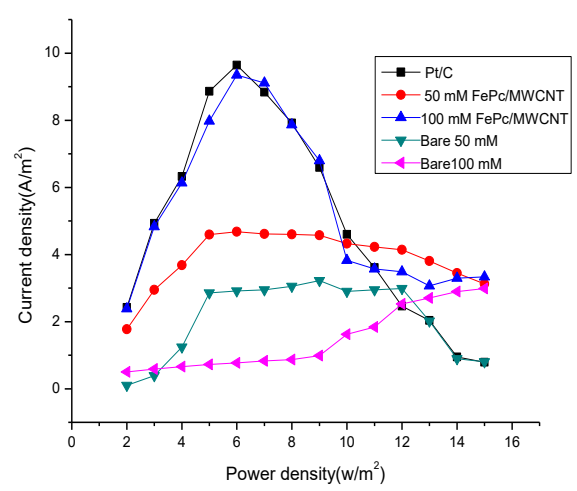

Figure 3. Power density versus current density for various electrolyte solutions

The power density of $9.3 \mathrm{~W} / \mathrm{m}^{2}$ from Fepc/MWCNT at 100 $\mathrm{mM}$ PBS in a composite catalyst coated is higher than bare electrode. The power density of $50 \mathrm{mM}$ PBS gives 501 $\mathrm{mW} / \mathrm{m}^{2}$ which is improved by $100 \mathrm{mM}$ PBS to $672 \mathrm{~mW} / \mathrm{m}^{2}$ and explained the effectiveness of electricity production as well as the treatment of paper recycling wastewater using MFC (Logan et al., 2008). Solution conductivity is a main factor for treatment of paper recycling effluent (Feng et al., 2008). Power density of FePc/MWCNT is comparably equal to the $\mathrm{Pt} / \mathrm{C}$ cathode catalyst. From the result MWCNT/FePc 
will be an excellent alternative to Pt in MFCs. Power density of FePc/KB was higher than FePc/vulcan-XC and slightly higher than Pt also (Yu et al., 2007). Power density obtained from fePc/MWCNT>Bare graphite felt, it shows the MWCNT as a good supporting material than Ketjan Black. Power density of MWCNT/FePc is much higher than the $\mathrm{KB} / \mathrm{FePc}$ (Yong et.al.,2011).

\subsection{COD removal and columbic efficiency}

To analyse the effectiveness of the catalyst in bio-electricity production by using paper recycling wastewater CE and percentage of COD removal are shown in Fig. 4. The maximum COD removal (73\%) and CE (8.4\%) are achieved from FePc/MWCNT deposited electrode. Due to longer operating time the bacteria will migrate from anode to cathode which affects the performance of fuel cell (LefebVre et al., 2011). By increasing the initial concentration, the COD removal efficiency can be improved (Mohan et al., 2008). This study reveals that the COD removal rate is also slightly higher for FePc/MWCNT than other electrodes.

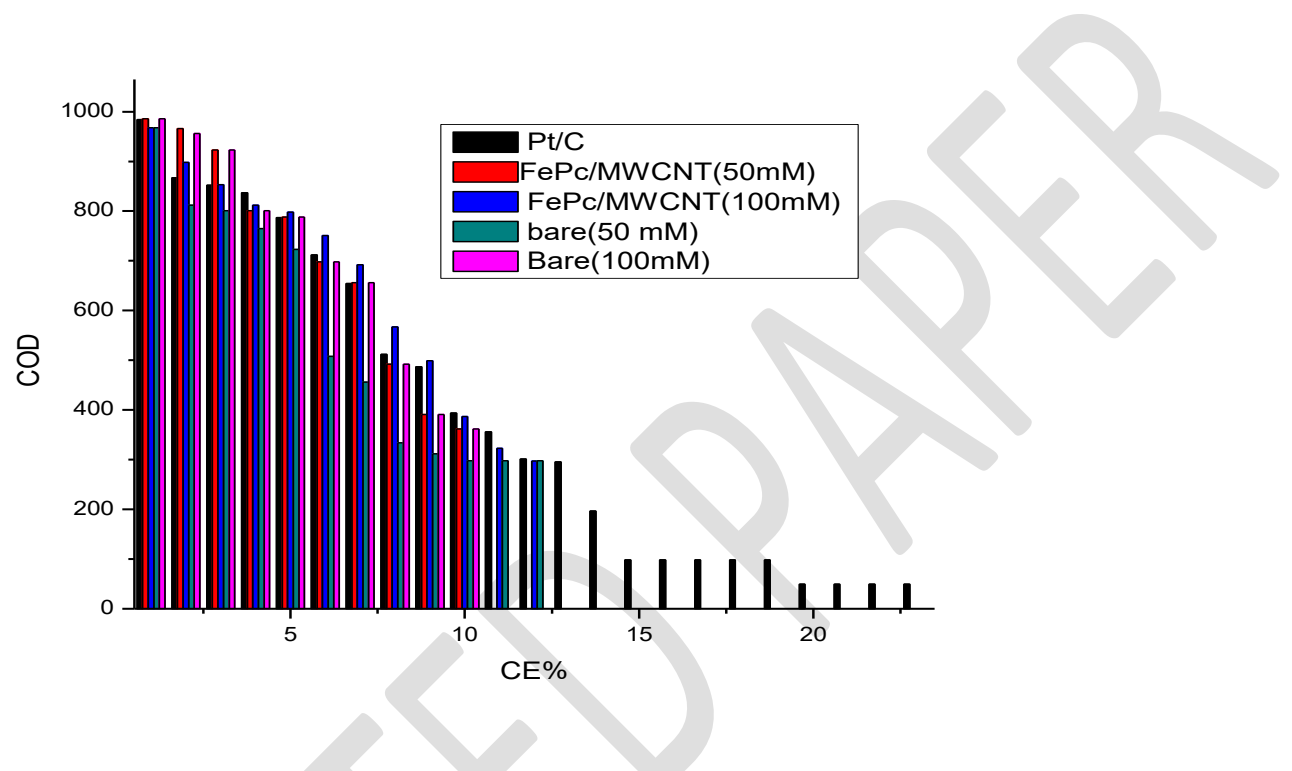

Figure 4. Effectiveness of the catalyst in bio-electricity production

\section{Conclusion}

This work conclude that the conductivity is increased by phosphate buffer solution by increasing the concentration from $50 \mathrm{mM}$ to $100 \mathrm{mM}$. The results exhibit that solution conductivity and buffer capacity are significant factors that can limit the amount of power generated from paper recycling effluent. Adding a phosphate buffer (100 mM PBS, $10.5 \mathrm{mS} / \mathrm{cm}$ ) demonstrate that the achievable power density produced by MWCNT/FePc is $9.34 \mathrm{~W} / \mathrm{m}^{2}$ was slightly lesser than $\mathrm{Pt} / \mathrm{C}\left(9.64 \mathrm{~W} / \mathrm{m}^{2}\right)$. In addition that long term stability and reasonable cost of MWCNT/FePc indicates it is a best alternative cathode catalyst in MFC.

\section{References}

Aelterman P., Rabaey K., Pham H.T., Boon N. and Verstraete W. (2006), Continuous electricity generation at high voltages and current using staked microbial fuel cell, Environmental Science and Technology, 10, 3388-3394.

Ahmed J., Yuan Y., Zhou L. and Kim S. (2012), Carbon supported cobalt oxide nanoparticles iron phthalocyanine as alternative cathode catalyst for oxygen reduction in microbial fuel cells, Journal of Power Sources, 208, 170-175.

Ayyaru S., Letchoumanane P., Dharmalingam S. and Stanislaus A.R. (2012), Performance of sulfonated polystyrene-ethylenebutylene -polystyrene membrane in microbial fuel cell for Bioelectricity production, Journal of Power Sources, 217, 204-208.
Birry L., Mehta P., Jaouen F., Dodelet J.P., Guiot S.R. and Tartakovsky B. (2011), Application of iron-based cathode catalysts in a microbial fuel cell, Electrochemical Acta, 56, 1505-1511.

Chandra A. and Singh I. (2013), Need for optimizing catalyst loading for achieving affordable microbial fuel cells, Bioresource Technology, 147, 77-81.

Feng Y.J., Wang X., Logan B.E. and Lee H. (2008), Brewery wastewater treatment using air-cathode microbial fuel cells, Applied Microbiology and Biotechnology, 78, 873-880

Ghamesi M., Ismail M., Kamarudin S.K., Saeedfar K., Daud W.R.W., Hassan S.H.A., Heng L.Y., Alam J., Oh S.-E. (2013), Carbon nanotube as an alternative cathode support and catalyst for microbial fuel cells, Applied Energy, 102, 1050-1056.

Gong K.P., Du F., Xia Z.H., Durstock M. and Dai L.M. (2009), Nitrogen-doped carbon nanotube arrays with high electrocatalytic activity for oxygen reduction, Science, 323, 760-764.

Ha S. and Kim S. (1999), Preparation and characterization of solgel derived carbon composite ceramic electrodes: electrochemical and XANES study of nitrite reduction, Journal of Electroanalytical Chemistry, 468, 131-138.

Jang J.K., Phama T.H., Chang S., Kang K.H., Moon H., Cho K.S. and Kim B.H. (2004), Construction and operation of a novel mediator and membrane less MFC, Process Bio Chemistry, 39, 1007-1012.

Leebana V.J., Santhanam S., Geetha K. and Raj A.S. (2012), Biodegradation of direct golden yellow, a textile dye by 
Pseudomonasputida, Desalination and Water Treatment, 39, 1-9.

Lefebvre O., Shen Y., Tan Z., Uzabiaga A., Chang I.S. and Ng H.Y. (2011), A comparison of Membranes and enrichment strategies for microbial fuel cells, Bioresource Technology, 102, 6291-9294.

Li H., Lai B., Wang P., Du Z., Wang L., Bi S. (2013), Calcined polyaniline-iron composite as a high efficient cathodic catalyst in microbial fuel cells, Bioresource Technology, 131, 321-324.

Li. X., Zhu N., Wang Y., Li P., Wu P. and Wu J. (2013), Animal carcass wastewater treatment and bioelectricity generation in upflow tubular Microbial fuel cells: Effects of HRT and nonprecious metallic catalyst, Bioresource Technology, 128, 454-460.

Limson J., Mshoperi E. and Foge R. (2014), Application of carbon black and iron phthalocyanine composites in bioelectricity production at a brewery wastewater fed microbial fuel cell, Electrochemical Acta, 128, 311-317.

Logan E. and Haung L. (2008), Electricity generation and treatment of paper recycling wastewater using microbial fuel cell, Applied Microbiology and Biotechnology, 80,349-355.

Lovely D.R. and Bond D.R. (2003), Electricity generation by geobacter sulfurreducens attaced to the electrodes, Applied Environmental Microbiology, 69, 1548-1555.

Lu M., Guo L., Kharkwal S., Wu H., Yong Ng H. and Li S.F.Y. (2013), Manganese-polypyrrole-carbon nanotube, a new oxygen reduction catalyst for air-cathode microbial fuel cells, Journal of Power Sources, 221, 381-386.

Lu W.Y., Li N., Chen W.X. and Yao Y.Y. (2009), The role of multiwalled carbon nanotubes in enhancing the catalytic activity of cobalt tetraaminophthalocyanine for oxidation of conjugated dyes, Carbon, 47, 3337-3345.

Mohan S.V., Mohanakrishna G. and Sarma P. (2008), Effect of anodic metabolic function on bioelectricity generation and substrate degradation in single chambered microbial fuel cell, Environmental Science and Technology, 42, 8088-8094.

Mohan Y., Muthu Kumar M. and Das D. (2008), Electricity generation using microbial fuel cell, International Journal of Hydrogen Energy, 33,423-426.

Velasquez-Orta S.B. (2011), Factors affecting current production in MFC using different industrial wastewater, Bio Resource Technology, 102, 5105-5112.

Yu E.H., Cheng S., Scott K. and Logan B.E. (2007), Microbial Fuel Cell with non platinum catalyst, Journal of power sources, 171, 275-282.

Yuan Y., Ahmed J. and Kim S. (2011), Polyaniline/Carbon black composite-supported iron phthalocyanine as an oxygen reduction catalyst for microbial fuel cells, Journal of Power Sources, 196, 1103-1106.

Yuan Y., Zhao B., Jeon Y., Zhong S., Zhou S. and Kim S. (2011), Iron phthalocyanine supported on amino-functionalized multiwalled carbon nanotube as an alternative cathodic oxygen catalyst in microbial fuel cells, Bio resource Technology, 102, 5849-5854.

Yuan Y., Zhao S.K.B., Jeon Y., Zhong S. and Zhou S. (2011), Iron Phthalocyanine supported on amino-functionalised multiwalled carbon nanotubes as an alternative cathode catalyst in microbial fuel cell, Bioresource Technology, 102, 5849-5854.
Zhao F., Harnisch F., Schröder U., Scholz F., Bogdanoff P. and Herrmann I. (2005), Application of pyrolysed iron(II) phthalocyanine and CoTMPP based oxygen reduction catalysts as cathode materials in microbial fuel cells, Electrochemical Communication, 7, 1405-1410.

Zhu K. and Logan B.E. (2013), Using single-chamber microbial fuel cells as renewable sources of electro-fenton reactors for organic pollutant treatment, Journal of Hazardous Materials, (252-253), 198-203. 